\title{
Differential expression of $m R N A s$ encoding the putative inhibin co-receptor (betaglycan) and activin type-I and type-II receptors in preovulatory and prehierarchical follicles of the laying hen ovary
}

\author{
T M Lovell, P G Knight and R T Gladwell \\ School of Animal and Microbial Sciences, University of Reading, Whiteknights, Reading RG6 6AJ, UK \\ (Requests for offprints should be addressed to T M Lovell; Email: t.m.lovell@reading.ac.uk)
}

\begin{abstract}
Ovarian follicle development is primarily regulated by an interplay between the pituitary gonadotrophins, LH and $\mathrm{FSH}$, and ovary-derived steroids. Increasing evidence implicates regulatory roles of transforming growth factor- $\beta$ (TGF $\beta$ ) superfamily members, including inhibins and activins. The aim of this study was to identify the expression of mRNAs encoding key receptors of the inhibin/activin system in ovarian follicles ranging from $4 \mathrm{~mm}$ in diameter to the dominant $\mathrm{F} 1$ follicle $(\sim 40 \mathrm{~mm})$.

Ovaries were collected $(n=16)$ from mid-sequence hens maintained on a long-day photoschedule $(16 \mathrm{~h}$ of light:8 h of darkness). All follicles removed were dissected into individual granulosa and thecal layers. RNA was extracted and cDNA synthesized. Real-time quantitative PCR was used to quantify the expression of mRNA encoding betaglycan, activin receptor (ActR) subtypes (type-I, -IIA and -IIB) and glyceraldehyde-3-phosphate dehydrogenase (GAPDH); receptor expression data were normalized to GAPDH expression. Detectable levels of ActRI, -IIA and -IIB and the inhibin co-receptor (betaglycan) expression were found in all granulosa and thecal layers analysed. Granulosa ActRI mRNA peaked $(P<0.05)$ in $8-9.9 \mathrm{~mm}$ follicles, whereas ActRIIA rose significantly from $6-7.9 \mathrm{~mm}$ to $8-9.9 \mathrm{~mm}$, before falling to F3/2; levels then rose sharply (3-fold) to F1 levels. Granulosa betaglycan mRNA expression rose 3-fold from $4-5.9 \mathrm{~mm}$ to $8-9.9 \mathrm{~mm}$, before falling 4-fold to $\mathrm{F} 3 / 2$;
\end{abstract}

levels then rose sharply (4-fold) to F1 levels. ActRIIB levels did not vary significantly during follicular development. Thecal ActRI mRNA expression was similar from $4-7.9 \mathrm{~mm}$ then decreased significantly to a nadir at the F4 position, before increasing 2 -fold to the F1 $(P<0 \cdot 05)$. Although thecal ActRIIB and -IIA expression did not vary significantly from $4 \mathrm{~mm}$ to $\mathrm{F} 3$, ActRIIB expression increased significantly (2-fold) from F3 to F1 and ActRIIA increased 2-fold from F2 to F1 $(P<0 \cdot 05)$. Thecal betaglycan fell to a nadir at F6 after follicle selection; levels then increased significantly to $\mathrm{F} 2$, before falling $\sim 50 \%$ in the F1.

In all follicles studied expression of betaglycan and ActRI (granulosa: $r=0.65, \quad P<0 \cdot 001, \quad n=144$ /group; theca: $r=0 \cdot 49, P<0 \cdot 001, n=144$ /group) was well correlated. No significant correlations were identified between betaglycan and ActRIIA or -IIB. Considering all follicles analysed, granulosa mRNA expression of betaglycan, ActRI, ActRIIA and ActRIIB were all significantly lower than in corresponding thecal tissue (betaglycan, 11.4-fold; ActRIIB, 5·1-fold; ActRI, 3·8-fold; ActRIIA, 2·8-fold). The co-localization of type-I and -II activin receptors and betaglycan on granulosa and thecal cells are consistent with a local auto/paracrine role of inhibins and activins in modulating ovarian follicle development, selection and progression in the domestic fowl.

Journal of Endocrinology (2006) 188, 241-249

\section{Introduction}

The mechanisms controlling ovarian follicular dynamics in the hen are complex and involve the interplay between neuroendocrine, endocrine, paracrine and autocrine signals. The pituitary gonadotrophins, luteinizing hormone (LH) and follicle-stimulating hormone (FSH), are key regulators which have been shown to stimulate production of ovarian steroids (Tilly et al. 1991a,b) and peptides including inhibin and activin (Lovell et al. 2002a) in a development-related manner. As in mammals, inhibins

and activins of gonadal origin have been implicated as regulators of follicle development and progression in the hen (for review see Knight et al. 2005).

Inhibins and activins are members of the structurally conserved but functionally diverse transforming growth factor- $\beta$ (TGF $\beta$ ) superfamily of extracellular signalling molecules (Knight \& Glister 2003). Inhibins are dimeric glycoproteins consisting of an $\alpha$-subunit disulphide linked to one of two distinct $\beta$-subunits ( $\beta \mathrm{A}$ or $\beta \mathrm{B}$ ), to generate inhibin $A$ and inhibin $B$ respectively. Activins are disulphide-linked homo- or hetero-dimers of $\beta \mathrm{A}$ and/or 
$\beta B$ subunits, termed activin $A(\beta A-\beta A)$, activin $B(\beta B-\beta B)$ and activin $A B(\beta A-\beta B)$. Divergent production of dimeric inhibin $A$, inhibin $B$ and activin $A$ and the activin-binding protein follistatin has been identified throughout the prehierarchical and selected ovarian follicle hierarchy (Lovell et al. 1998, 2003) consistent with a fully operational intraovarian inhibin-activin system.

The receptors and downstream signal transduction cascade through which activins exert their biological effects are well characterized (Zimmerman \& Mathews 1996). Activins bind to and form a hetero-oligomeric complex with two types of cell-surface receptors (ActRs), designated type-I and type-II. Two ActRII subtypes (A and B) have been cloned in avian (Ohuchi et al. 1992, Nohno et al. 1993, Stern et al. 1995) and mammalian species (Donaldson et al. 1992, Ethier et al. 1994) and both have a high affinity binding site for activin. ActRI exists as two subtypes (A and B) in mammals (Attisano et al. 1993, Tsuchida et al. 1995) but only one subtype has so far been identified in birds. The binding of activin to ActRIIs promotes the recruitment of type-I receptors to the complex which then mediates ligand signalling by Smads; these translocate to the nucleus to modulate gene transcription (Kawabata et al. 1999, Knight \& Glister 2003).

The membrane-anchored proteoglycan, betaglycan (also known as TGF $\beta I I I$ receptor), has been reported to serve as an accessory receptor for inhibin. The affinity of inhibin for the ActRII is enhanced in the presence of betaglycan (Lewis et al. 2000). ActRII present in the inhibin/betaglycan/ActRII complex is therefore unable to bind activin and recruit the ActRI to initiate downstream signal transduction. The functional antagonism between inhibin and activin may thus be explained by their interactions with betaglycan and ActRIIs coexpressed on the cell surface (Phillips \& Woodruff 2004).

The avian ovary provides a unique model for the study of folliculogenesis as the single left ovary contains follicles of various sizes and developmental stages including quiescent primordial follicles, prehierarchical growing follicles and large yolk-filled follicles that have been recruited into a well-ordered preovulatory hierarchy. The objectives of the present study were first to determine whether activin receptor subtypes (ActRI, ActRIIA and ActRIIB) and the inhibin co-receptor, betaglycan, are expressed in the hen ovary, and secondly to quantify mRNA expression levels throughout the granulosa and thecal layers of prehierarchical and preovulatory follicles in order to gain an insight into potential endocrine and/or local ovarian roles of the inhibins and activins in the avian reproductive system.

\section{Materials and Methods}

\section{Experimental animals}

Laying hens (Goldline) towards the end of the first year of lay, with a clutch average of at least five eggs, were caged individually and maintained under a standard long-day photo-schedule of $16 \mathrm{~h}$ of light and $8 \mathrm{~h}$ of darkness, at an ambient temperature of $21-23{ }^{\circ} \mathrm{C}$. Food and water were freely available. Ovipositions were monitored using timelapse recording technology and used to predict the time of ovulation.

\section{Recovery and preparation of follicle extracts}

Hens $(n=16)$ were killed by cervical dislocation $4 \mathrm{~h}, 12 \mathrm{~h}$, $18 \mathrm{~h}$ and $22 \mathrm{~h}$ after the predicted ovulation of a midsequence egg. Ovarian follicles of $4 \mathrm{~mm}$ in diameter and above were dissected from the ovary and their diameters recorded. All follicles were subsequently dissected into separate granulosa and thecal layers (Gilbert et al. 1977) which were washed in saline $(0 \cdot 75 \%(\mathrm{w} / \mathrm{v}))$, snap frozen in solid $\mathrm{CO}_{2}$ and stored at $-70{ }^{\circ} \mathrm{C}$.

Granulosa and thecal tissues from $\geq 10 \mathrm{~mm}$ follicles and six separate granulosa and thecal follicle pools from 4-5.9 mm, 6-7.9 $\mathrm{mm}$ and $8-9.9 \mathrm{~mm}$ follicles were weighed and homogenized in an $\sim 15$ times volume of Tri-reagent (Sigma) using an Ultra-Turrax T8 homogenizer (IKA, Staufen, Germany). RNA was subsequently purified as described in the standard Tri-reagent protocol. The final RNA pellet was resuspended in $100 \mu l$ nuclease-free water (containing RNA Secure (Ambion, Huntington, Cambridgeshire, UK)), then treated with RNase-free DNase (15 min at $37^{\circ} \mathrm{C}$; RQ1; Promega). The purified RNA was re-purified using a 15 times volume of Tri-reagent. The resultant purified RNA was resuspended in 50 $\mathrm{\mu l}$ nuclease-free water (containing RNA Secure).

RNA was quantified on a spectrophotometer (GeneQuant; GE Healthcare, Amersham) and cDNA was synthesized using ImProm-II reverse transcriptase (Promega; used according to the supplier's instructions) with $1 \mu \mathrm{g}$ RNA, $0.5 \mu \mathrm{g}$ random hexamer primers (MWG-Biotech, Covent Garden, London, UK), dNTPS $(0.5 \mathrm{mM}$ final; Promega) and $0.5 \mu \mathrm{l}$ RNase inhibitor ( $40 \mathrm{U} / \mu \mathrm{l}$; Ambion) per reaction. cDNA synthesis was terminated by heat inactivation $\left(15 \mathrm{~min}\right.$ at $\left.70^{\circ} \mathrm{C}\right)$. cDNA samples were treated with $1 \mu \mathrm{l}$ RNase cocktail $(0 \cdot 5 \mathrm{U} / \mu \mathrm{l}$ RNase A and $20 \mathrm{U} / \mu \mathrm{l}$ RNase T1; Ambion) and $0.5 \mu \mathrm{l}$ RNase $\mathrm{H}(40 \mathrm{U} / \mu \mathrm{l}$; Ambion) which specifically degrades the RNA in RNA:DNA hybrids. A $1 \mu$ aliquot of cDNA was removed for estimation using a fluorometric assay (Oligreen ssDNA quantification assay; Molecular Probes Inc., Paisley, Renfrewshire, UK).

\section{Quantitative PCR}

Duplicate quantitative PCR reactions were carried out using $1 \mu \mathrm{l}$ diluted RT reaction product or $1 \mu \mathrm{l}$ standard (from 200 to $1.56 \mathrm{amol} / \mu \mathrm{l}$ ), in a volume of $25 \mu \mathrm{l}$ containing $12.5 \mu \mathrm{l}$ master mix with $1 \mu \mathrm{l}$ ROX dye (Abgene, Epsom, Surrey, UK), $2 \mu$ forward and reverse primers 
Table 1 TaqMan primer and probe sequences used

\begin{tabular}{|c|c|c|c|c|}
\hline & Forward primer $5^{\prime}$ to $3^{\prime}$ & Reverse primer $5^{\prime}$ to $3^{\prime}$ & TaqMan probe $5^{\prime}$ (6-FAM) to $3^{\prime}$ (TAMRA) & Accession number \\
\hline \multicolumn{5}{|l|}{ Target } \\
\hline ActRI & ccggaggtcttggacgaaа & gcccagatatcgaccctcttg & catccaggcagactgcttcgactcc & AJ318064 \\
\hline ActRIIA & tcacgaaaagggttcattaactga & ctgagcaatgtgacacagctcat & ttcctcaaggctaacgtggttcctgg & D31899 \\
\hline ActRIIB & tccctgcttaacatcctggtgta & ccaagaggatggccactga & tctctgctgcccatcgctgtcct & U31223 \\
\hline Betaglycan & atgaagcttgcacctctctgaat & gacaagaggcttggtgaaggttt & tggatatgatcttggccatgatgcaca & L01121 \\
\hline GAPDH & ggagtcaacggatttggcc & tttgccagagaggacggc & tattggccgcctggtcaccagg & K01458 \\
\hline
\end{tabular}

(see Table 1) were each added (final concentration: 50-900 nM), $1 \mu \mathrm{l}$ probe (final concentration: 100$200 \mathrm{nM}$; see Table 1) and $5 \cdot 5 \mu \mathrm{l}$ nuclease-free water. The samples were processed for 40 cycles using an ABI Prism 7700 Sequence detector (Applied Biosystems, Warrington, Cheshire, UK) with the thermal cycler conditions: stage $1,50{ }^{\circ} \mathrm{C} / 2 \mathrm{~min}$; stage $2,95^{\circ} \mathrm{C} / 15 \mathrm{~min}$; stage 3 , 40 cycles of $95^{\circ} \mathrm{C} / 15 \mathrm{~s}$ and $60^{\circ} \mathrm{C} / 1 \mathrm{~min}$. TaqMan primers and probes were designed to target mRNA sequence based on criteria set by Applied Biosystems.

\section{Statistical analysis}

One-way ANOVA was used in conjunction with post hoc Fisher's protected least significant difference (PLSD) test to determine whether expression of mRNAs encoding receptors varied between different follicular size categories. Levels of expression of each mRNA detected were normalized to glyceraldehyde-3-phosphate dehydrogenase (GAPDH) mRNA. $P<0 \cdot 05$ was considered to be significant. Values are the means \pm S.E.M. Preliminary assessment of the follicular gene expression results obtained from hens killed at the four different time-points during the ovulatory cycle $(n=4$ hens per time-point) revealed a high degree of individual variation; results for all 16 hens were therefore combined for further analysis and presentation.

\section{Results}

Granulosa cell expression of $m R N A$ for ActRI, ActRIIA and ActRIIB

Changes in granulosa expression of mRNAs encoding ActRI, ActRIIA and ActRIIB during follicle development are shown in Fig. 1. Expression of the three activin receptor subtypes was measurable in all follicle size classes studied (4 mm-F1). ActRI mRNA expression remained at a similar level from $4-7.9 \mathrm{~mm}(43.2 \pm 4.5 \mathrm{amol} / \mathrm{fmol}$ GAPDH); levels increased significantly $(P<0 \cdot 05)$ to a peak at $8-9.9 \mathrm{~mm}(101.7 \pm 27 \cdot 7 \mathrm{amol} / \mathrm{fmol} \mathrm{GAPDH})$ before falling in the F6 follicles $(31 \cdot 0 \pm 6 \cdot 2 \mathrm{amol} / \mathrm{fmol}$ GAPDH). Expression levels in F6-F1 follicles were not significantly different from those in $4-7.9 \mathrm{~mm}$ follicles. Considering all follicle size classes, granulosa ActRI mRNA expression was 5- to 20-fold higher than ActRIIB expression. However, there was no significant difference in granulosa ActRIIB mRNA expression throughout follicular development $(4 \cdot 4 \pm 0.59 \mathrm{amol} / \mathrm{fmol}$ GAPDH, $n=144$ /group). ActRIIA expression level was similar to ActRI expression

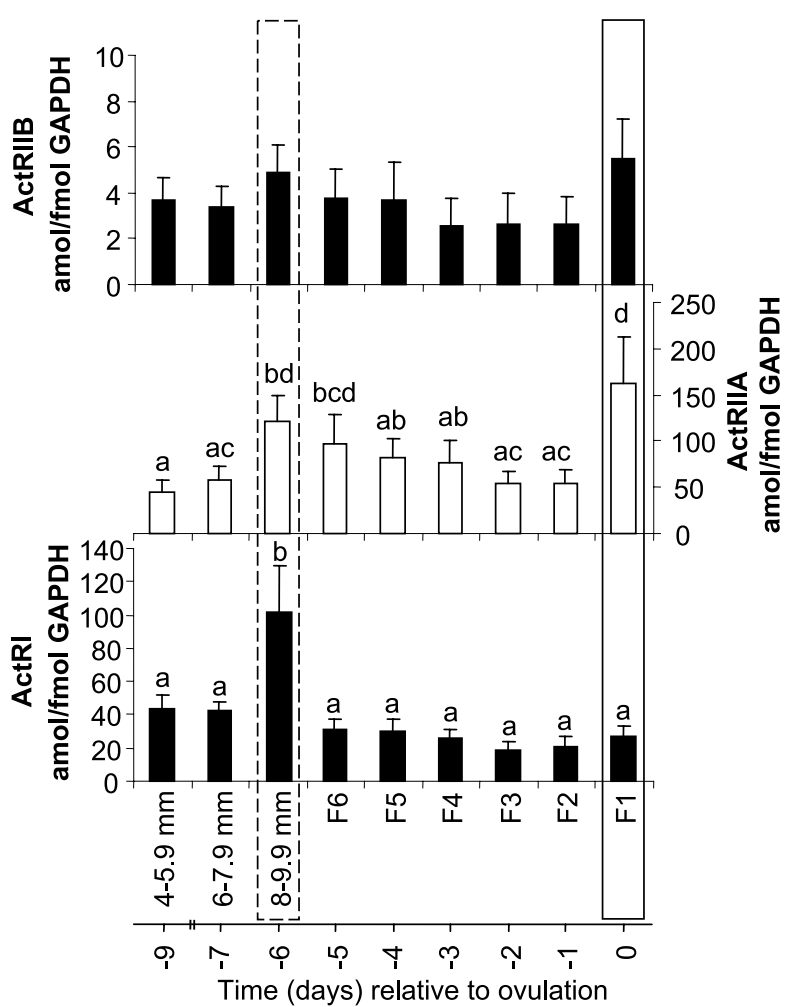

Figure 1 Expression of mRNA for ActRI, ActRIIA and ActRIIB in the granulosa layer of chicken ovarian follicles ranging in size from $4 \mathrm{~mm}$ to $\sim 40 \mathrm{~mm}$ (F1). Fn represents the hierarchical order with the largest follicle designated F1. Values are means \pm S.E.M. $(n=16)$ and means without a common letter are significantly $(P<0 \cdot 05)$ different (by ANOVA and Fisher's PLSD test). mRNA levels are normalized to GAPDH mRNA. The lower time-scale provides an estimation of the time taken for follicles of a given size category to reach the point of ovulation (based on the observation of Gilbert et al. (1983)). The solid line and broken line boxes identify the next follicle to undergo ovulation (F1) and the follicle cohort $(8-9.9 \mathrm{~mm})$ from which the next preovulatory follicle will be selected, respectively. 


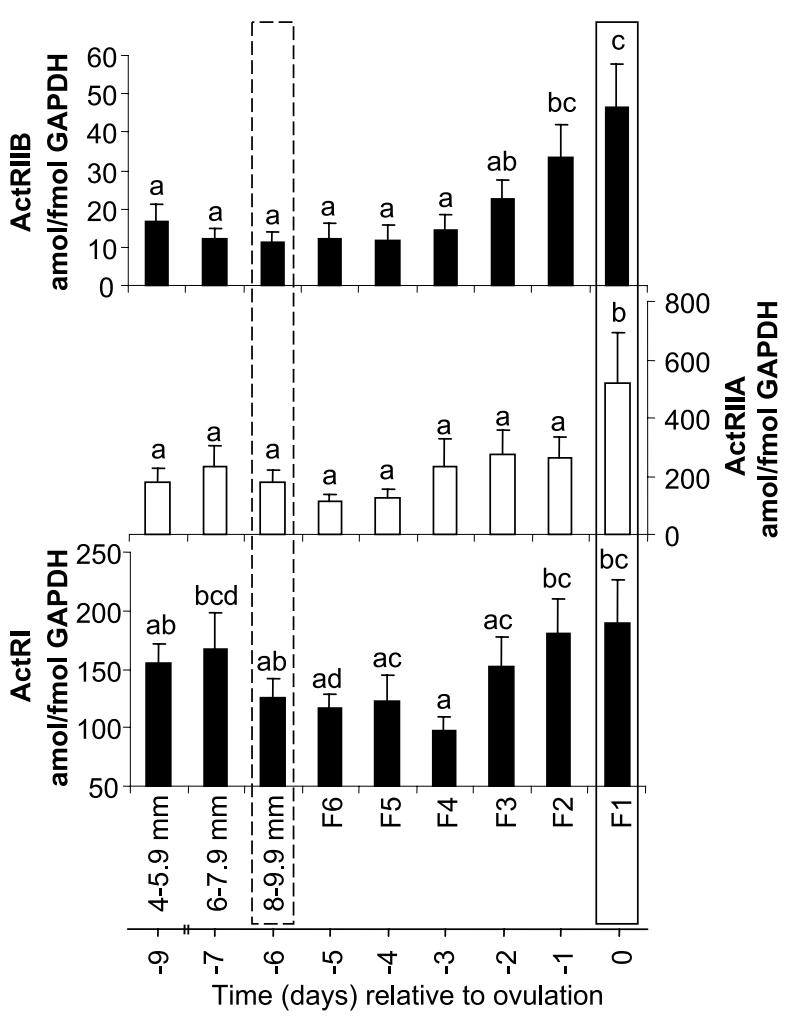

Figure 2 Expression of mRNA for ActRI, ActRIIA and ActRIIB in the thecal layer of chicken ovarian follicles ranging in size from $4 \mathrm{~mm}$ to $\sim 40 \mathrm{~mm}$ (F1). Other details are as given in the legend to Fig. 1.

in $4-7.9 \mathrm{~mm}$ follicles $(51.5 \pm 9.6 \mathrm{amol} / \mathrm{fmol}$ GAPDH); ActRIIA levels rose significantly in the $8-9.9 \mathrm{~mm}$ class $(121.6 \pm 26 \cdot 8 \mathrm{amol} / \mathrm{fmol}$ GAPDH $)$ before falling progressively up to F2 (8.99 $\mathrm{mm}$ vs F2, $P<0 \cdot 05)$. Expression then rose sharply from F2 to F1 (3-fold; $53 \cdot 7 \pm 15$ vs 161. $4 \pm 51 \mathrm{amol} / \mathrm{fmol}$ GAPDH, $P<0 \cdot 05)$. Overall, ActRIIA mRNA expression was 2.5- to 6-fold higher than ActRI expression in preovulatory granulosa cells. ActRIIA expression was well correlated with ActRIIB expression in the granulosa of the F1 follicles $(r=0.664$, $P<0 \cdot 01, n=16 /$ group $), \quad 4-5.9 \mathrm{~mm}$ follicles $(r=0.662$, $P<0 \cdot 01, n=16 /$ group) and weakly correlated throughout follicle development $(r=0 \cdot 24, P<0 \cdot 05, n=144$ /group). ActRI mRNA expression was correlated with ActRIIA $(r=0.584, P<0 \cdot 01, n=16 /$ group $)$ and ActRIIB $(r=0.534$, $P<0 \cdot 01, n=16$ /group) but only in $4-5 \cdot 9 \mathrm{~mm}$ follicles.

\section{Thecal cell expression of $m R N A$ for ActRI, ActRIIA} and ActRIIB

Changes in thecal expression of mRNAs encoding ActRI, ActRIIA and ActRIIB during follicle development are shown in Fig. 2. All activin receptor subtypes were measurable in all follicle size classes studied (4 mm-F1).

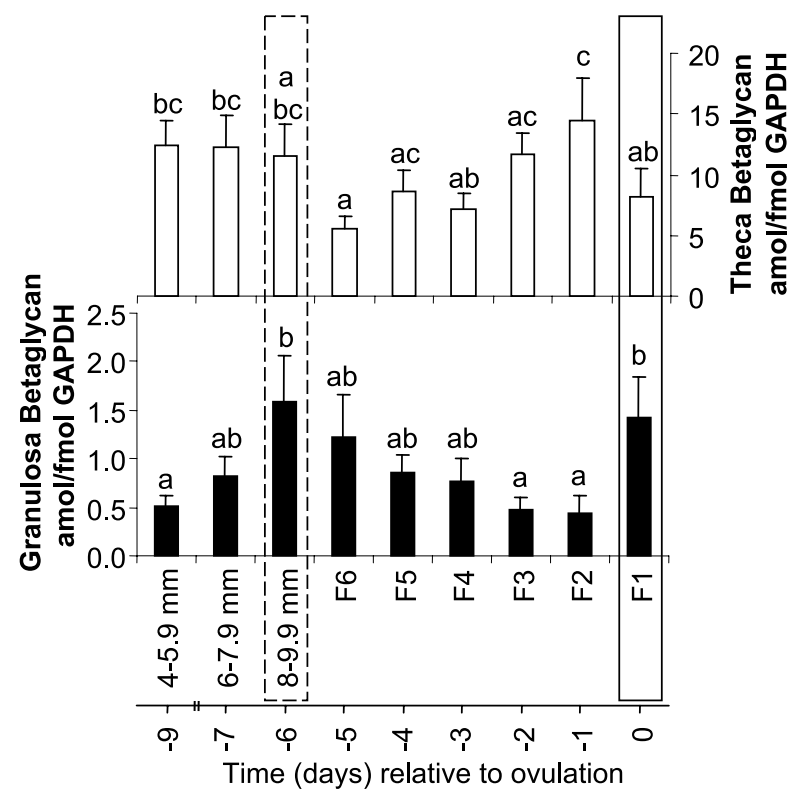

Figure 3 Expression of mRNA for the inhibin co-receptor, betaglycan, in the granulosa and thecal layer of chicken ovarian follicles ranging in size from $4 \mathrm{~mm}$ to $\sim 40 \mathrm{~mm}$ (F1). Other details are as given in the legend to Fig. 1 .

ActRI mRNA expression was similar from $4-7 \cdot 9 \mathrm{~mm}$ $(160 \cdot 5 \pm 17 \cdot 9 \mathrm{amol} / \mathrm{fmol}$ GAPDH); levels decreased significantly from $6-7.9 \mathrm{~mm}$ to a nadir at the F4 position $(97 \cdot 9 \pm 12 \cdot 0 \mathrm{amol} / \mathrm{fmol}$ GAPDH; $P<0 \cdot 05)$. Expression then rose significantly $(P<0 \cdot 05)$ to the F1 $(189 \pm 36 \cdot 8$ amol/fmol GAPDH). Thecal ActRIIA mRNA expression was not significantly different from $4 \mathrm{~mm}$ to F2 $(180 \cdot 6 \pm 44 \cdot 4$ to $262 \cdot 5 \pm 73 \cdot 9 \mathrm{amol} / \mathrm{fmol}$ GAPDH); however, expression increased 2-fold from F2 to F1 $(521 \cdot 9 \pm 173 \cdot 4 \mathrm{amol} / \mathrm{fmol}$ GAPDH, $P<0 \cdot 05)$. Thecal ActRIIB expression was not significantly different from $4 \mathrm{~mm}$ to F3 $(16 \cdot 6 \pm 4 \cdot 6$ to $22 \cdot 3 \pm 5 \cdot 3 \mathrm{amol} / \mathrm{fmol}$ GAPDH) although expression significantly increased 2-fold from F3 to F1 $(46 \cdot 5 \pm 11 \cdot 2 \mathrm{amol} / \mathrm{fmol} \mathrm{GAPDH}$, $P<0 \cdot 05)$. ActRIIA mRNA expression was correlated with ActRIIB expression in F1 $(r=0.783, \quad P<0.01$, $n=16$ /group $)$ and with ActRIIB $(r=0.521, P<0 \cdot 01$, $n=144$ /group $)$ and ActRI $(r=0 \cdot 229, P<0 \cdot 05, n=144$ / group) expression throughout follicle development. Relative to ActRI expression, the relative expression of ActRIIA increased 3-fold from F6 to F1. Thecal ActRIIB expression was significantly lower than both ActRIIA (7- to 20-fold) and ActRI (4- to 14-fold) at all follicle stages analysed.

\section{Granulosa and thecal cell expression of $m R N A$ for betaglycan}

Changes in granulosa and thecal expression of mRNA encoding betaglycan during follicle development are shown in Fig. 3. Betaglycan was measurable in the 

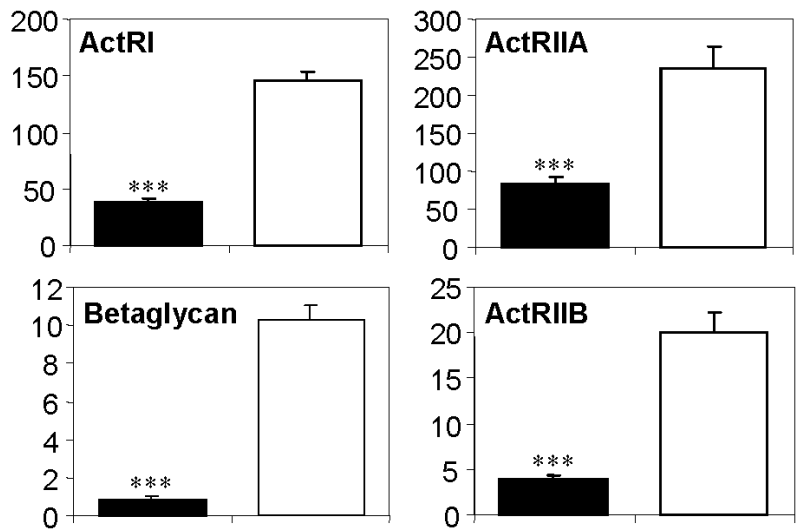

Figure 4 Comparison of expression of mRNAs encoding ActRI, ActRIIA and ActRIIB and the inhibin co-receptor (betaglycan) in granulosa and thecal layers of hen follicles. Values are the means \pm S.E.M. $(n=144)$ and represent the combined data for all nine follicle stages analysed $(4 \mathrm{~mm}-\mathrm{F} 1) .{ }^{* \star} P<0 \cdot 001$.

granulosa and thecal layers of all follicle size classes studied (4 mm-F1). Granulosa betaglycan mRNA expression increased 3-fold from $4-5.9 \mathrm{~mm}(0.5 \pm 0 \cdot 1 \mathrm{amol} / \mathrm{fmol}$ GAPDH) to a peak at $8-9.9 \mathrm{~mm}(1.6 \pm 0.4 \mathrm{amol} / \mathrm{fmol}$ GAPDH). Levels then fell as follicles progressed through the preovulatory hierarchy, being $\sim 4$-fold lower at the $\mathrm{F} 3$ and $\mathrm{F} 2$ positions (F2; $0.43 \pm 0.18 \mathrm{amol} / \mathrm{fmol}$ GAPDH). Granulosa expression then peaked abruptly $(P<0 \cdot 05)$ in $\mathrm{F} 1$ (4-fold increase; $1.4 \pm 0.41 \mathrm{amol} / \mathrm{fmol}$ GAPDH). In contrast, thecal betaglycan expression remained relatively high in the prehierarchical follicles $(4-8.9 \mathrm{~mm} ; 12 \cdot 1 \pm 1.4 \mathrm{amol} / \mathrm{fmol}$ GAPDH, $n=48)$ before falling $\sim 2$-fold in the F6 position $(6-7.9 \mathrm{~mm}$ vs F6. $P<0 \cdot 05)$. Betaglycan mRNA expression increased through the preovulatory hierarchy to the F2 position (F6 vs F2; $P<0 \cdot 05$ ), before falling significantly from F2 to F1 $(14.5 \pm 3.4$ vs $8.1 \pm 2.4 \mathrm{amol} / \mathrm{fmol}$ GAPDH $)$. Betaglycan mRNA expression in the theca was between 4.5-fold (F6) and 34-fold (F2) higher than in the corresponding granulosa layer.

\section{Relationship among ActRI, ActRIIA and ActRIIB and betaglycan in ovarian follicles}

Considering the combined data for all classes of follicle stages analysed (4 mm-F1; see Fig. 4), granulosa expression of betaglycan, ActRI, ActRIIA and ActRIIB mRNAs were all significantly lower (as expressed relative to GAPDH) than in corresponding thecal tissue (betaglycan, 11.4-fold; ActRIIB, 5.1-fold; ActRI, 3.8-fold; ActRIIA, 2.8-fold). In all follicles studied there was a good correlation between mRNA expression of betaglycan and ActRI (granulosa: $r=0 \cdot 65, P<0 \cdot 001, n=144$ / group; theca: $r=0.50, \quad P<0.001, n=144$ /group). No significant correlations were identified between betaglycan and ActRIIA or ActRIIB when analysing the granulosa or thecal layers independently. Considering all follicle stages, there was a positive correlation between granulosa and thecal ActRIIB mRNA expression $(r=0.45$, $P<0 \cdot 001, n=144$ /group) with particularly high correlations between the granulosa and thecal layer in F1 $(r=0.69, \quad n=16 /$ group $), \quad 8-9.9 \mathrm{~mm} \quad(r=0.74, \quad n=16 /$ group), $6-7.9 \quad(r=0.86, n=16 /$ group $)$ and $4-5.9 \mathrm{~mm}$ $(r=0 \cdot 65, n=16 /$ group $)$ follicles. Betaglycan mRNA expression in granulosa and theca was highly correlated in the $6-7 \cdot 9 \mathrm{~mm}$ follicle category $(r=0 \cdot 88, P<0 \cdot 001, n=16 /$ group) but not at other follicle stages.

\section{Discussion}

The present study used quantitative PCR (TaqMan) to examine for the first time the spatio-temporal pattern of expression of mRNAs encoding activin receptors (ActRI, ActRIIA and ActRIIB) and betaglycan throughout folliculogenesis in an avian species, although recent studies have confirmed that betaglycan is expressed in ovarian follicles (Sweeney \& Johnson 2005) and that ActRIIA is expressed in the broiler hen ovary (Slappey \& Davis 2003).

Our results have shown detectable expression of mRNA for betaglycan, ActRI, ActRIIA and ActRIIB within the granulosa and thecal layers of all follicle stages analysed, with mRNA expression for all receptors much higher in the thecal than in the granulosa layer. These differences may reflect differential steroidogenic potential and/or inhibin-related protein production (Etches \& Duke 1984, Lovell et al. 1998, 2003). Thecal cells produce steroids at all stages of follicle development but granulosa cells from prehierarchical $(3-8 \mathrm{~mm})$ hen follicles are steroidogenically incompetent (Tilly et al. 1991b). Inhibin A is also undetectable in granulosa cells of follicles $<9 \mathrm{~mm}$ although they produce inhibin B, activin A and follistatin (Lovell et al. 2003). The action of activin would be greatest when follistatin levels are low. Similarly, since inhibins antagonize the actions of activin, low levels of inhibin should also favour activin action. As shown previously (Lovell et al. 2003) follicular activin A content was relatively uniform in follicles ranging from 1 to $9 \mathrm{~mm}$ while follistatin content increased progressively from 1 to $7 \mathrm{~mm}$, suggesting a gradual attenuation of 'activin tone'. The surge in inhibin B production in follicles between $5 \mathrm{~mm}$ and $8 \mathrm{~mm}$ would further diminish 'activin tone' relative to 'inhibin tone' at this stage.

The primary source of oestrogen in the hen ovary is the thecal layer of small prehierarchical follicles (Senior \& Furr 1975, Robinson \& Etches 1986) which, as reported here, have detectable mRNA expression of all activin receptor subtypes. Furthermore, addition of oestradiol to cultured laying hen granulosa cells from small yellow follicles and large white follicles increased follistatin and 
activin $\beta \mathrm{B}$-subunit mRNA expression, with no increase in immunoreactive $\alpha$-subunit protein (Davis et al. 2000), suggesting that theca-derived oestrogen may regulate granulosa inhibin $\mathrm{B}$, or possibly activin B production in prehierarchical follicles.

In the avian ovary, one prehierarchical 6-8 $\mathrm{mm}$ follicle is 'selected' daily to enter the preovulatory follicle hierarchy from approximately six to ten visually similar follicles. Selection is thought to be governed by sensitivity to FSH, with the highest FSH receptor (FSH-R) mRNA content detected in this class (You et al. 1996). In contrast to observations in mammals (Nakamura et al. 1993), activin A was unable to induce FSH-R mRNA expression in cultured hen granulosa cells from $6-8 \mathrm{~mm}$ follicles (Woods \& Johnson 2005). This may be due to endogenous follistatin production neutralizing the activin A treatment, as granulosa follistatin production peaks in 8-8.9 mm follicles (Lovell et al. 2003) and addition of anti-follistatin antisera facilitates the effects of activin on FSH-R mRNA expression (Woods \& Johnson 2005). Activin A did stimulate FSH-R mRNA levels in granulosa cells from $6-8 \mathrm{~mm}$ follicles when combined with FSH treatment, suggesting that activin can sensitize follicles to FSH action (Johnson et al. 2004).

In a previous study (Lovell et al. 2001), juvenile hens were actively immunized (IMM) against a synthetic chicken inhibin $\alpha$-subunit peptide (amino acids $1-26$ ). At 26 weeks, IMM hens showed a 2 -fold increase in the numbers of $8-9.9 \mathrm{~mm}$ follicles. This size class normally corresponds to follicles around the point of entry to the preovulatory follicle hierarchy; they also show a peak in inhibin B production (Lovell et al. 2003). Whether IMM altered expression of ActRs and/or betaglycan, thus changing follicular responsiveness, needs further evaluation. However, the absence of significant changes in plasma LH and FSH after inhibin immunization (Lovell et al. 2001) and the absence of changes in plasma FSH during the laying hen ovulatory cycle (Lovell et al. 2000) suggest that inhibin may reduce the FSH responsiveness of this follicle population. It is suggested that exogenous activin A treatment and immunoneutralization of endogenous follistatin or inhibin $\alpha$-subunit raises 'activin tone' relative to 'inhibin tone', allowing normally unselected follicles with a higher inhibin:activin ratio and/or betaglycan expression to be selected into the hierarchy. This concept is reinforced by the present finding of a peak in mRNA expression for ActRIIA, ActRI and betaglycan in the granulosa layer of $8-9 \cdot 9 \mathrm{~mm}$ follicles.

This leads us to hypothesize that one 'privileged' follicle of the growing small yellow follicle (SYF) cohort is promoted to the preovulatory hierarchy each cycle by virtue of its having an intrinsically high 'activin tone' and significant expression of ActRI and ActRII, with a low 'inhibin tone' and/or low level of betaglycan. In this study there was always a strong positive correlation between ActRI and betaglycan, suggesting that the balance between activin and inhibin signalling components is tightly regulated. In vivo it is likely that a cocktail of factors, including FSH, activin, follistatin and inhibin together, regulate FSH-R expression. Incubation of 6-8 mm follicle granulosa cells with FSH renders them responsive to LH stimulation (Tilly et al. 1991b) with increased progesterone production ( $\mathrm{Li} \&$ Johnson 1993a,b). Preliminary attempts to identify such 'privileged' 6-9 $\mathrm{mm}$ follicles by examining basal and gonadotrophin-induced hormone secretion by individual follicle wall explants in vitro have yielded inconclusive results (authors' unpublished observations). However, Woods \& Johnson (2005) recently detected individual follicles in the 6-9 $\mathrm{mm}$ cohort expressing elevated FSH-R mRNA expression. Whether these individual follicles have a high 'activin tone' and/or elevated ActRs with low inhibin and/or betaglycan expression remains to be determined.

Expression of activin receptors has also been identified in mammalian ovaries with ActRIIA and ActRIIB protein in early follicles from the cow (Hulshof et al. 1997) and ActRIIA, ActRIIB, ActRIA and ActRIB in the rat (Drummond et al. 2002). The present study identified ActRIIB mRNA as being the least abundant of the activin subtypes; this was also demonstrated in the postnatal rat ovary (Drummond et al. 2002). However, although ActRIIB mRNA expression is lower than ActRIIA during follicle development it may still contribute a higher proportion of activin receptor protein than expression suggests. In vitro studies have shown that activin A can stimulate early follicle development in cows (Hulshof et al. 1997), sheep (Thomas et al. 2003) and rodents (Liu et al. 1998, Smitz et al. 1998, Zhao et al. 2001), implicating it as a modulator of early follicular development in mammals. Factors regulating expression of ActRI, ActRIIA, ActRIIB and betaglycan in the hen ovary have yet to be explored; however, expression of ActRIA and ActRIIA is regulated by gonadotrophins and oestradiol in adult rats (Aloi et al. 1997).

Lovell et al. (2003) showed that transition into the preovulatory hierarchy was associated with a marked rise in thecal activin A ( $\sim 8$-fold rise; $8 \mathrm{~mm}-\mathrm{F} 4)$ and a decline in the follistatin ( $\sim 5$-fold) and inhibin B ( $\sim 27$-fold $)$ content of the granulosa layer from $8 \mathrm{~mm}$ to $\mathrm{F} 1$ (Lovell et al. 2003). This increase in activin A, decrease in inhibin A or decrease in follistatin, or any combination would enhance the paracrine signalling of theca-derived activin A through type-I and -II activin receptors expressed on granulosa tissue. As shown here, ActRIIA mRNA levels fell progressively from follicle selection to F2 with no significant change in ActRI expression from F6 to F1. Whether the reduction in ActRIIA expression reduces activin-stimulated events is unknown; however, the reduction in granulosa betaglycan expression (between $8 \mathrm{~mm}$ and F2) and the increase in 'activin tone' would be expected to facilitate activin function. 
In hens, LH receptor (LH-R) mRNA expression was first detected in 9-12 $\mathrm{mm}$ granulosa tissue (Johnson et al. 1996). This LH sensitivity enables selected cells to produce progesterone in respond to LH (Asem \& Hertelendy 1985). Treatment of F4/5 granulosa cells with LH stimulates LH-R mRNA expression; however, activin A prevented this induction (Davis et al. 2001), suggesting that activin A could act to regulate follicular maturation by preventing excessive or untimely LH-R expression. The reduction in ActRIIA (this study) and activin A (Lovell et al. 2003) suggests that the gradual reduction in activin activity could lead to increased LH-R expression as seen in F3-F1 granulosa cells (Johnson et al. 1996).

Inhibin A production increased progressively $(\sim 100-$ fold increase from $5-6 \mathrm{~mm}$ to $\mathrm{F} 1$ ) as follicles progress through the preovulatory hierarchy (Lovell et al. 1998, 2003). Various factors have been shown to modulate secretion of inhibin A and progesterone from cultured chicken F1-F3 granulosa cells including FSH, LH, TGF $\alpha$, insulin-like growth factor-I and activin A (Onagbesan \& Peddie 1995, Lovell et al. 2002a,b). Changes in plasma inhibin A mirror the F1 granulosa inhibin A content, peaking around the time of the LH surge (Lovell et al. 2000) and may be involved in endocrine regulation of pituitary gonadotroph function, through interaction with betaglycan and ActRIIA as described by Lovell et al. (2005). The fact that the transition from F2 to F1 coincides with a significant increase in granulosa betaglycan and ActRIIA expression, with no alteration in ActRI, suggests that the F1 granulosa itself may be a key target for inhibin action in an autoregulatory feedback manner.

Inhibin A from granulosa cells may also modulate thecal steroid production by antagonizing the action of activin. Changes in thecal expression of betaglycan appear to mirror previously reported changes in thecal androstenedione production with levels increasing from $\mathrm{F} 4$ to a peak in F2 before decreasing in the F1 follicles (Llewelyn 1981, Etches \& Duke 1984, Marrone \& Hertelendy 1985). In mammals, inhibins stimulate and activin inhibits LH-induced androgen production by thecal cells (Hillier et al. 1991a,b, Wrathall \& Knight 1995). Indeed, Rombauts et al. (1996) reported that inhibin and activin also have this antagonistic effects on androstenedione production by primary ovarian cells derived from chicken embryos. It is therefore likely that inhibin acting through betaglycan/ActRII binding has a paracrine action on thecal androstenedione production.

In conclusion, taken together with previous reports documenting the spatio-temporal pattern of expression of inhibins, activins and follistatin in the hen ovary, the present finding of divergent expression of activin receptor subtypes and the putative inhibin co-receptor, betaglycan, reinforce the view that inhibin, acting through betaglycan and ActRIIA/B and activins acting through ActRI and ActRIIA/B may play key roles during folliculogenesis in the avian ovary.

\section{Acknowledgements}

We thank Mr S A Feist for skilled technical assistance and BBSRC for financial support (grant 45/S17120). The authors declare that there is no conflict of interest that would prejudice the impartiality of this scientific work.

\section{References}

Aloi JA, Marshall JC, Yasin M, Gilrain JT, Haisenleder \& Dalkin AC 1997 Ovarian activin receptor subtype and follistatin gene expression in rats: reciprocal regulation by gonadotropins. Biology of Reproduction 56 1565-1569.

Asem EK \& Hertelendy F 1985 Influence of follicular maturation on luteinizing hormone-, cyclic $3^{\prime}, 5^{\prime}$-adenosine monophosphate-, forskolin- and cholesterol-stimulated progesterone production in hen granulosa cells. Biology of Reproduction 32 257-268.

Attisano L, Carcamo J, Ventura F, Weis FMB, Massague J \& Wrana JL 1993 Identification of human activin and TGF $\beta$ type I receptors that form heteromeric kinase complexes with type II receptors. Cell 75 671-680.

Davis AJ, Brooks CF \& Johnson PA 2000 Estradiol regulation of follistatin and inhibin $\alpha$ and $\beta \mathrm{B}$-subunit mRNA in avian granulosa cells. General and Comparative Endocrinology 119 308-316.

Davis AJ, Brooks CF \& Johnson PA 2001 Activin A and gonadotropin regulation of follicle-stimulating hormone and luteinizing hormone messenger RNA in avian granulosa cells. Biology of Reproduction 65 1352-1358.

Donaldson CJ, Mathews LS \& Vale WW 1992 Molecular cloning and binding properties of the human type-II activin receptor. Biochemical and Biophysical Research Communications 184 310-316.

Drummond AE, Le MT, Ethier JF, Dyson M \& Findlay JK 2002 Expression and localisation of activin receptors, Smads and betaglycan to the postnatal rat ovary. Endocrinology 143 1423-1433.

Etches RJ \& Duke CE 1984 Progesterone, androstenedione and oestradiol content of theca and granulosa tissue of the four largest ovarian follicles during the ovulatory cycle of the hen (Gallus domesticus). Journal of Endocrinology 103 71-76.

Ethier JF, Houde A, Lussier JG \& Silversides DW 1994 Bovine activin receptor type II cDNA: cloning and tissue expression. Molecular and Cellular Endocrinology 106 1-8.

Gilbert AB, Evans AJ, Perry MM \& Davidson MH 1977 A method for separating the granulosa cells, the basal lamina and the theca of the preovulatory ovarian follicle of the domestic fowl (Gallus domesticus). Journal of Reproduction and Fertility 50 179-181.

Gilbert AB, Perry MM, Waddington D \& Hardie MA 1983 Role of atresia in establishing the follicular hierarchy in the ovary of the domestic hen (Gallus domesticus). Journal of Reproduction and Fertility 69 221-227.

Hillier SG, Yong EL, Illingworth PJ, Baird DT, Schwall RH \& Mason AJ 1991a Effect of recombinant activin on androgen synthesis in cultured human thecal cells. Journal of Clinical Endocrinology and Metabolism 72 1206-1211.

Hillier SG, Yong EL, Illingworth PJ, Baird DT, Schwall RH \& Mason AJ $1991 b$ Effect of recombinant inhibin on androgen synthesis in cultured human thecal cells. Molecular and Cellular Endocrinology 75 R1-R6.

Hulshof SCJ, Figueiredo JR, Beckers JF, Bevers MM, Vanderstichele H \& van der Hurk R 1997 Bovine preantral follicles and activin: immunohistochemistry for activin and activin receptor and the effect of bovine activin A in vitro. Theriogenology 48 133-142.

Johnson AL, Bridgham JT \& Wagner B 1996 Characterization of a chicken luteinizing hormone receptor (cLH-R) complementary deoxyribonucleic acid, and expression of cLH-R messenger ribonucleic acid in the ovary. Biology of Reproduction 55 304-309. 
Johnson AL, Bridgham JT \& Woods DC 2004 Cellular mechanisms and modulation of activin $\mathrm{A}$ and transforming growth factor beta-mediated differentiation in cultured hen granulosa cells. Biology of Reproduction 71 1884-1851.

Kawabata M, Imamura T, Inoue H, Hanai J, Nishihara A, Hanyu A, Takase M, Ishidou Y, Udagawa Y, Oeda E et al. 1999 Intracellular signaling of the TGF-beta superfamily by Smad proteins. Annals of the New York Academy of Sciences 886 73-82.

Knight PG \& Glister C 2003 Local roles of TGF $\beta$ superfamily members in the control of ovarian follicle development. Animal Reproduction Science 78 165-183.

Knight PG, Gladwell RT \& Lovell TM 2005 The inhibin-activin system and ovarian folliculogenesis in the chicken. In Functional Avian Endocrinology, pp 323-337. Eds A Dawson \& P J Sharp. New Delhi, India: Narosa Publishing House.

Lewis KA, Gray PC, Blount AL, MacConell LA, Wiater E, Bilezikjian LM \& Vale W 2000 Betaglycan binds inhibin and can mediate functional antagonism of activin signalling. Nature 404 411-414.

Li Z \& Johnson AL 1993a Regulation of P450 cholesterol side-chain cleavage messenger ribonucleic acid expression and progesterone production in hen granulosa cells. Biology of Reproduction 49 463-469.

Li Z \& Johnson AL $1993 b$ Expression and regulation of cytochrome P450 17 $\alpha$-hydroxylase messenger ribonucleic acid levels and androstenedione production in hen granulosa cells. Biology of Reproduction 49 1293-1302.

Liu X, Andoh K, Yokota H, Hobayashi J, Abe Y, Yamada K, Mizunuma H \& Ibuki Y 1998 Effect of growth hormone, activin, and follistatin on the development of preantral follicles from immature female mice. Endocrinology 139 2342-2347.

Llewelyn CA 1981 Conversion of $\left[4-{ }^{14}\right.$ C]progesterone to androstenedione in vitro by thecal tissue from the ovary of the domestic fowl (Gallus domesticus). Journal of Endocrinology $89283-288$.

Lovell TM, Gladwell RT, Cunningham FJ, Groome NP \& Knight PG 1998 Differential changes in inhibin A, activin A, and total $\alpha$-subunit levels in granulosa and thecal layers of developing preovulatory follicles in the chicken. Endocrinology 139 1164-1171.

Lovell TM, Vanmontfort D, Bruggeman V, Decuypere E, Groome NP, Knight PG \& Gladwell RT 2000 Circulating concentrations of inhibin-related proteins during the ovulatory cycle of the domestic fowl (Gallus domesticus) and after induced cessation of egg laying. Journal of Reproduction and Fertility 119 323-328.

Lovell TM, Knight PG, Groome NP \& Gladwell RT 2001 Changes in plasma inhibin A levels during sexual maturation in the female chicken and the effects of active immunization against inhibin $\alpha$-subunit on reproductive hormone profiles and ovarian function. Biology of Reproduction 64 188-196.

Lovell TM, Gladwell RT, Groome NP \& Knight PG 2002a Activin exerts differential effects on basal and gonadotrophin-induced secretion of inhibin A and progesterone by granulosa cells from preovulatory (F1-F3) follicles. Reproduction 124 649-657.

Lovell TM, Gladwell RT, Groome NP \& Knight PG $2002 b$ Modulatory effects of gonadotrophins and insulin-like growth factor on the secretion of inhibin A and progesterone by granulosa cells from chicken preovulatory (F1-F3) follicles. Reproduction 123 291-300.

Lovell TM, Gladwell RT, Groome NP \& Knight PG 2003 Ovarian follicle development in the laying hen is accompanied by divergent changes in inhibin A, inhibin B, activin A and follistatin production in granulosa and theca layers. Journal of Endocrinology $17745-55$.

Lovell TM, Knight PG \& Gladwell RT 2005 Variation in pituitary expression of $\mathrm{mRNAs}$ encoding the putative inhibin co-receptor (betaglycan) and type-I and type-II activin receptors during the chicken ovulatory cycle. Journal of Endocrinology 186 447-455.
Marrone BL \& Hertelendy F 1985 Decreased androstenedione production with increased follicular maturation in theca cells from the domestic hen (Gallus domesticus). Journal of Reproduction and Fertility 74 543-550.

Nakamura M, Minegishi T, Hasegawa Y, Nakamura K, Igarashi S, Ito I, Shinozaki H, Miyamoto K, Eto Y \& Ibuki Y 1993 Effect of activin A on follicle-stimulating hormone (FSH) receptor messenger ribonucleic acid levels and FSH receptor expression in cultured rat granulosa cells. Endocrinology 133 538-544.

Nohno T, Noji S, Koyama E, Myokai F, Ohuchi H, Nishikawa K, Sumitomo S, Taniguchi S \& Saito T 1993 Expression patterns of the activin receptor IIA and IIB genes during chick limb development. Progress in Clinical and Biological Research 383B 705-714.

Ohuchi H, Noji S, Koyama E, Myokai F, Nishikawa K, Nohno T, Tashiro K, Shiokawa K, Matsuo N \& Taniguchi S 1992 Expression pattern of the activin receptor type IIA gene during differentiation of chick neural tissues, muscle and skin. FEBS Letters 303 185-189.

Onagbesan OM \& Peddie MJ 1995 Effects of insulin-like growth factor I and interactions with transforming growth factor $\alpha$ and LH on proliferation of chicken granulosa cells and production of progesterone in culture. Journal of Reproduction and Fertility 104 259-265.

Perry MM, Waddington D, Gilbert AB \& Hardie MA 1983 Growth rates of the small yolky follicles in the ovary of the domestic fowl. IRCS Medical Science 11 979-980.

Phillips DJ \& Woodruff TK 2004 Inhibin: actions and signalling. Growth Factors 22 13-18.

Robinson FE \& Etches RJ 1986 Ovarian steroidogenesis during follicular maturation in the domestic fowl (Gallus domesticus). Biology of Reproduction 35 1096-1105.

Rombauts L, Vanmontfort D, Decuypere E \& Verhoeven G 1996 Inhibin and activin have antagonistic paracrine effects on gonadal steroidogenesis during the development of the chicken embryo. Biology of Reproduction 54 1229-1237.

Senior BE \& Furr BJA 1975 A preliminary assessment of the source of oestrogen within the ovary of the domestic fowl, Gallus domesticus. Journal of Reproduction and Fertility 43 241-247.

Slappey SN \& Davis AJ 2003 Expression pattern of messenger ribonucleic acid for the activin type II receptors and the inhibin/activin subunits during follicular development in broiler breeder hens. Poultry Science 82 338-344.

Smitz J, Cortvrindt R, Hu Y \& Vanderstichele H 1998 Effect of recombinant activin A on in vitro culture of mouse preantral follicles. Molecular Reproduction and Development 50 294-304.

Stern CD, Yu RT, Kakizuka A, Kintner CR, Mathews LS, Vale WW, Evans RM \& Umesono K 1995 Activin and its receptors during gastrulation and the later phases of mesoderm development in the chicken embryo. Developmental Biology 172 192-205.

Sweeney SA \& Johnson PA 2005 Messenger RNA and protein expression analysis of betaglycan in the pituitary and ovary of the domestic hen. Biology of Reproduction 72 172-178.

Thomas FH, Armstrong DG \& Telfer EE 2003 Activin promotes oocyte development in ovine preantral follicles in vitro. Reproductive Biology and Endocrinology 176.

Tilly JL, Kowalski KI \& Johnson AL 1991 a Cytochrome P450 side-chain cleavage (P450 scc) in the hen ovary. II. P450 scc messenger RNA, immunoreactive protein, and enzyme activity in developing granulosa cells. Biology of Reproduction 45 967-974.

Tilly JL, Kowalski KI \& Johnson AL $1991 b$ Stage of ovarian follicle development associated with the initiation of steroidogenic competence in avian granulosa cells. Biology of Reproduction 44 305-314.

Tsuchida K, Vaughan JM, Wiater E, Gaddy-Kurten D \& Vale WW 1995 Inactivation of activin-dependent transcription by kinase-deficient activin receptors. Endocrinology 136 5493-5503. 
Woods DC \& Johnson AL 2005 Regulation of follicle-stimulating hormone-receptor messenger RNA in hen granulosa cells relative to follicle selection. Biology of Reproduction 72 643-650.

Wrathall JHM \& Knight PG 1995 Effects of inhibin-related peptides and oestradiol on androstenedione and progesterone secretion by bovine theca cells in vitro. Journal of Endocrinology 145 491-500.

You S, Bridgham JT, Foster DN \& Johnson AL 1996 Characterisation of the chicken follicle-stimulating hormone receptor ( $\mathrm{cFSH}-\mathrm{R}$ ) complementary deoxyribonucleic acid, and expression of cFSH-R messenger ribonucleic acid in the ovary. Biology of Reproduction 55 1055-1062.
Zhao J, Taverne MAM, van der Weijden GC, Bevers MM \& van der Hurk R 2001 Effect of activin A on in vitro development of rat preantral follicles and localization of activin A and activin receptor II. Biology of Reproduction 65 967-977.

Zimmerman CM \& Mathews LS 1996 Activin receptors: cellular signalling by receptor serine kinases. Biochemical Society Symposium 62 25-38.

Received 3 November 2005 Accepted 26 November 2005 